ARTICLE

Received 9 Mar 2015 | Accepted 5 Jun 2015 | Published 21 Jul 2015

DOl: $10.1038 /$ ncomms8719

OPEN

\title{
Carbohydrate scaffolds as glycosyltransferase inhibitors with in vivo antibacterial activity
}

\author{
Johannes Zuegg1,2, Craig Muldoon², George Adamson², Declan McKeveney², Giang Le Thanh², \\ Rajaratnam Premraj ${ }^{2}$, Bernd Becker², Mu Cheng ${ }^{1}$, Alysha G. Elliott ${ }^{1}$, Johnny X. Huang ${ }^{1}$, Mark S. Butler ${ }^{1}$, \\ Megha Bajaj ${ }^{1}$, Joachim Seifert ${ }^{2}$, Latika Singh², Nicola F. Galley ${ }^{3}$, David I. Roper ${ }^{3}$, Adrian J. Lloyd ${ }^{3}$, \\ Christopher G. Dowson ${ }^{3}$, Ting-Jen Cheng ${ }^{4}$, Wei-Chieh Cheng ${ }^{4}$, Dieter Demon ${ }^{5}$, Evelyne Meyer ${ }^{5}$, \\ Wim Meutermans ${ }^{2} \&$ Matthew A. Cooper ${ }^{1}$
}

The rapid rise of multi-drug-resistant bacteria is a global healthcare crisis, and new antibiotics are urgently required, especially those with modes of action that have low-resistance potential. One promising lead is the liposaccharide antibiotic moenomycin that inhibits bacterial glycosyltransferases, which are essential for peptidoglycan polymerization, while displaying a low rate of resistance. Unfortunately, the lipophilicity of moenomycin leads to unfavourable pharmacokinetic properties that render it unsuitable for systemic administration. In this study, we show that using moenomycin and other glycosyltransferase inhibitors as templates, we were able to synthesize compound libraries based on novel pyranose scaffold chemistry, with moenomycin-like activity, but with improved drug-like properties. The novel compounds exhibit in vitro inhibition comparable to moenomycin, with low toxicity and good efficacy in several in vivo models of infection. This approach based on non-planar carbohydrate scaffolds provides a new opportunity to develop new antibiotics with low propensity for resistance induction.

\footnotetext{
${ }^{1}$ Institute for Molecular Bioscience, The University of Queensland, St Lucia, Queensland 4072, Australia. ${ }^{2}$ Alchemia Ltd, PO Box 4851, Eight Mile Plains, Brisbane, Queensland 4113, Australia. ${ }^{3}$ School of Life Science, University of Warwick, Gibbet Hill Road, Coventry CV4 7AL, UK. ${ }^{4}$ Genomics Research Center, Academia Sinica, 128 Academia Road, Section 2, Taipei 115, Taiwan. ${ }^{5}$ Faculty of Veterinary Medicine, Laboratory of Biochemistry, Ghent University, Salisburylaan 133, 9820 Merelbeke, Belgium. Correspondence and requests for materials should be addressed to W.M. (email: wmeutermans@optusnet.com.au) or to M.A.C. (email: m.cooper@uq.edu.au).
} 
eptidoglycan glycosyltransferases (GT) and transpeptidases (TP) are two key enzymes in the final steps of peptidoglycan (PG) biosynthesis essential for bacterial cell wall integrity and stability. GTs catalyse the polymerization of lipid II disaccharide units, forming a long chain of alternating $\beta$-1,4-linked $N$-acetylglucosamines and $N$-acetylmuramic acid, leading to a linear glycan chain and the release of undecaprenylpyrophosphate carrier $^{1-3}$. These carbohydrate chains are further crosslinked by TP enzymes, forming linkages between the peptide chain and the D-alanine of a neighboring unit (Fig. 1). GT and TP enzymes are unique to bacteria and are expressed either as individual domains, monofunctional GT (MGT) and penicillin-binding proteins (PBP), respectively or as bifunctional proteins that possess both GT and TP domains (class A PBP) ${ }^{4,5}$.

Inhibition of extracellular bacterial cell wall synthesis has been a very successful strategy in the development of many important antibacterial agents, with teixobactin ${ }^{6}$, one of the most recently reported. The $\beta$-lactam class, which includes cephalosporins, monobactams and carbapenems, inhibit PG crosslinking by covalently binding to the TP enzyme, while glycopeptides such as vancomycin bind directly to the lipid II unit and sterically inhibit further polymerization and crosslinking of PG. Bacteria developed resistance to cell wall inhibitors via $\beta$-lactamases, thickened cell walls and modification of the lipid II unit, with extended-spectrum $\beta$-lactamases such as NDM-1 and vancomycin-resistant enterococci representing a significant health threat ${ }^{7}$. Glycolipopeptides (for example, ramoplanin), cyclic peptides (for example, AC98-6446) and lantibiotics (for example, nisin or NVB302) also bind to lipid II of Gram-positive bacteria ${ }^{8}$. Only nisin has reached the market, and then only as a food preservative ${ }^{9}$.

Antibacterial compounds that bind directly to GT have never been developed for human use. Of the few examples reported in the literature, moenomycin is by far the best described ${ }^{10}$. Moenomycin is produced by various streptomyces species and has a broad-spectrum activity against a range of Gram-positive bacteria. The poor pharmacokinetic properties of moenomycin have prevented further clinical development ${ }^{10,11}$, and it has been commercialized only as a 'growth promoter' within animal feed stocks (Flavomycin and Flavophospholipol). Despite evidence that regular application of antibiotics as growth promoters in animals in general leads to increased antibiotic resistance ${ }^{12,13}$, remarkably no moenomycin-resistant bacteria in animals have been reported to date $\mathrm{e}^{14,15}$. In vitro resistance induction experiments showed extremely slow development of resistance with low-resistant frequencies ${ }^{16}$, as well as no transferable resistance between organisms ${ }^{17,18}$, no cross-resistance to other antimicrobials or co-selection of resistant strains ${ }^{19}$. Intrinsic resistance in moenomycin-producing organisms is not associated with the biosynthesis cluster, but is likely to arise from the presence of GT's with low affinity for moenomycin, or some peculiarities of their cell wall organization ${ }^{10}$. Further, moenomycin is primarily accumulated inside of the cells, while its target is located on the cell surface ${ }^{20,21}$. In vitro-induced resistance with $S$. aureus showed mutations in the binding site of PBP2 with reduced affinity for moenomycin as well as its ligand, resulting in strains with shorter $P G$ polymers and major cell division defects ${ }^{16}$. The lack of a specific resistance mechanism and the paucity of antibiotics that specifically mimic the carbohydrate portion of bacterial lipid II suggest that direct GT inhibition remains an attractive strategy for the development of novel antibacterial agents with low potential for resistance development.

Moenomycin A is a highly functionalized pentasaccharide attached via a phosphoglycerate linkage to a polyprenyl chain ${ }^{22}$ (Fig. 1) that binds competitively to GT enzymes by mimicking the disaccharide-pyrophosphate-prenol linkage of the donor lipid

a

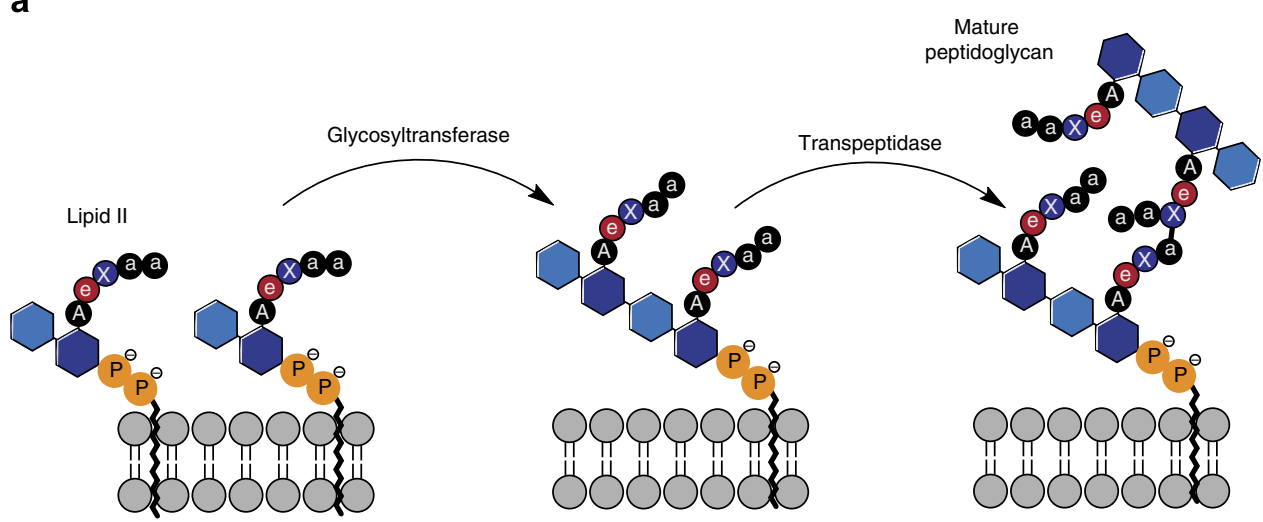

b

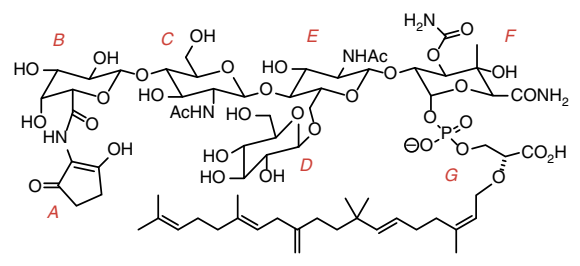

Moenomycin A

TG inhibition: $54 \%$ at $0.1 \mu \mathrm{g} \mathrm{ml}^{-1}$ MIC: $0.098 \mu \mathrm{g} \mathrm{ml}^{-1}$ (S.aureus SG511) c

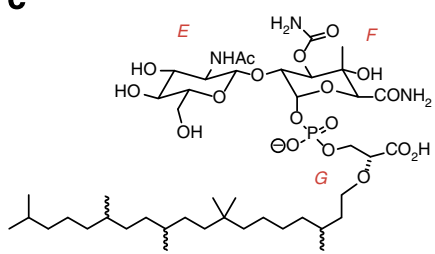

Disaccharide-degradation product TG inhibition: $45 \%$ at $0.1 \mu \mathrm{g} \mathrm{ml}^{-1}$ MIC: $>50 \mu \mathrm{g} \mathrm{ml}^{-1}$ (S.aureus SG511)

Figure 1 | Overview of PG cell wall synthesis and inhibitors. (a) PG synthesis in bacteria from lipid II with subsequent GT and TP catalysis, with A: L-Ala, a: D-Ala, e: D-iGln, X: either D-Lys $\left(\mathrm{Ala}_{5}\right)$ in case of Staphylococcus, or mDap in case of Bacillus. (b) Structure and in vitro activity of moenomycin A, indicating the different moieties with A to G. (c) Structure and in vitro activity of moenomycin's disaccharide degradation product. 
$\mathrm{II}^{10,23,24}$. Although the $\mathrm{E}$ and $\mathrm{F}$ rings and the phosphoglycerate (G) portion of moenomycin A are important for GT inhibitory activity, analogues of this pharmacophore subunit did not maintain whole cell antibacterial activity ${ }^{25,26}$. Attempts to mimic the EFG structural fragment with disaccharide derivatives $^{27-30}$ resulted in compounds (such as TS30153 (ref. 17)) with cell-based activity, that is, minimum inhibitory concentration (MIC) of 3.12 and $12.5 \mu \mathrm{g} \mathrm{ml}^{-1}$ against staphylococci and enterococci, but with no in vivo activity. Compound TS30153 (ref. 17) has three hydrophobic binding elements that mimic the acyl and alkyloxy moieties of moenomycin A (Fig. 2b). Attempts to mimic directly lipid $\mathrm{II}^{31}$, or the ring $\mathrm{F}$ of moenomycin ${ }^{32}$, with monosaccharide scaffolds gave compounds with only low to medium activity $(\mathrm{MIC}=60 \mu \mathrm{M}$ against Bacillus cereus ${ }^{31}$ ). More recently, de novo inhibitors for GT discovered using high-throughput screening ${ }^{33-35}$ or in silico methods ${ }^{36}$, were shown to have improved in vitro activity $\left(\mathrm{MIC}=0.25 \mu \mathrm{M}\right.$ against $\left.\mathrm{MRSA}^{33}\right)$, but no in vivo activity.

In this study, we explore novel chemistry based on a monosaccharide scaffold ${ }^{37}$ to mimic the essential structure features of moenomycin and to improve the drug-like properties, in particular reduced molecular weight and hydrophobicity. Compared with other scaffolds, the monosaccharide scaffold approach provides structural diversity using up to five chiral attachment points within a small volume ${ }^{38}$. This allows for more efficient pharmacophore optimization, while still enabling the generation of a broad structural diversity to scope and improve activity and physicochemical properties. Here we use the approach to produce moenomycin-focused libraries and select compounds with in vitro antibacterial activity and in silico potential to inhibit the GT enzyme. We demonstrate the strength of this strategy with two of the most promising candidates showing inhibition of GT and PG synthesis in in vitro assays, as well as in vivo efficacy in eliminating $S$. aureus infection from a mouse mammary gland.

\section{Results}

Design and synthesis. We synthesized a small library of compounds by replacing the phosphoglycerate/phosphate moieties (G, Fig. 1) with simpler lipophilic substituents (that is, phenyl, biphenyl or naphthyl groups linked via a urea) and changing the orientation and nature of ring $\mathrm{F}$. This approach yielded compounds like ACL19378 (Fig. 2a, Supplementary Figs 1-8) and ACL19333 (Supplementary Fig. 1), with MICs against Gram-positive bacteria in the range of $2 \mu \mathrm{g} \mathrm{ml}^{-1}$, but with limited activity in the presence of $50 \%$ serum. In the second stage, we used the disaccharide structure-activity relationship information to design more synthetically feasible and smaller monosaccharide molecules. A versatile solid-phase method was developed to rapidly synthesize the representatives of three different core chemotypes M1 to M3, starting from a single monosaccharide building block, that is, 1,5-anhydro-galactitol (see Fig. 3). Chemotype M1 explored the option of using only two of the hydrophobic elements, whereas the other two, M2 and M3, used a benzimidazole moiety as the third hydrophobic group (Fig. 3).

Five hundred compounds were thus synthesized combinatorially on solid-phase resin, purified using high-performance liquid chromatography, and tested for their MIC activity against two Gram-positive staphylococcal strains (methicillin-sensitive (MSSA) and methicillin-resistant $S$. aureus (MRSA)), three enterococcal strains and Escherichia coli as a Gram-negative control. Although most compounds were inactive against E. coli, many compounds displayed activity against the Gram-positive strains. The derivatives with Gram-positive antibacterial activity generally contained a lipophilic substituent such as an alkyl moiety (minimum length of 10 carbon atoms) or a biaryl, and one or two electron-deficient aryl groups. All active compounds were then tested for haemolytic activity and, after filtering out the haemolytic compounds, a series of compounds of chemotype M3 containing substituted amino-benzimidazoles were selected for further study (Supplementary Table 1). Two compounds (Fig. 4), ACL20215 (Supplementary Figs 10-15) and ACL20964 (Supplementary Figs 16-20), showed broad activity against a range of drug resistant $S$. aureus strains, including MRSA, GISA (glycopeptideintermediate $S$. aureus), VRSA (vancomycin-resistant $S$. aureus) and DRSA (daptomycin-resistant $S$. aureus) and multi-drugresistant $S$. pneumoniae, with low haemolytic activity against human red blood cells (Table 1). ACL20215 was assayed for resistance potential and showed a spontaneous mutation frequency against $S$. aureus (ATCC 13709; Smith strain) of less than $2.5 \times 10^{-10}$ at four times its MIC value. a

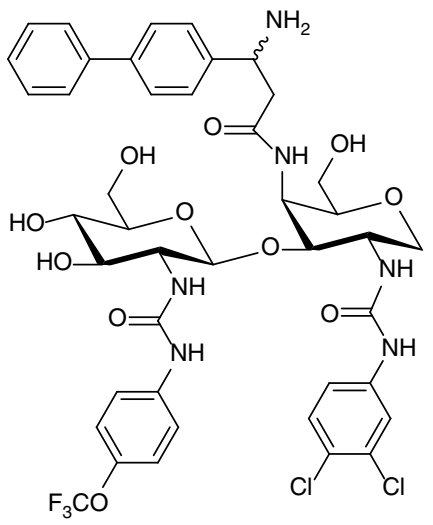

ACL19378

MIC: $2 \mu \mathrm{g} \mathrm{ml}^{-1}$

(S. aureus) b

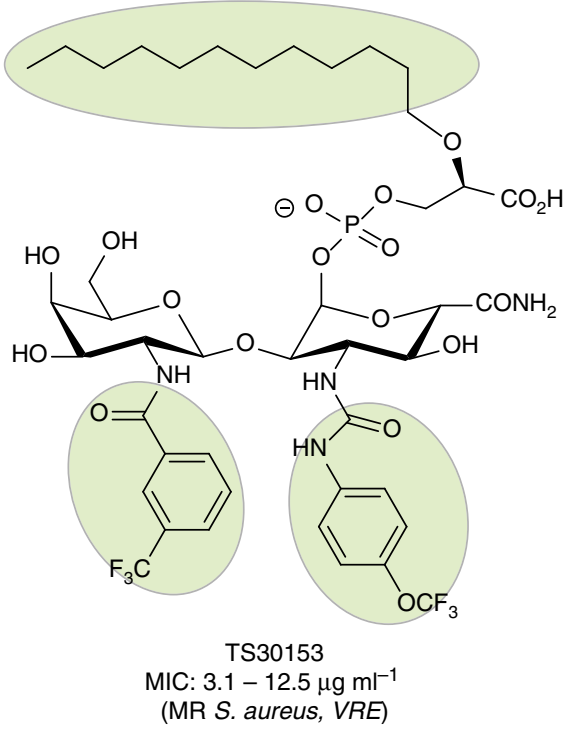

Figure 2 | Disaccharide templates for design of monosaccharides. (a) ACL19378, representative compounds from disaccharide library. (b) TS30153 (ref. 27) highlighting the three binding elements required for GT inhibition in green. 


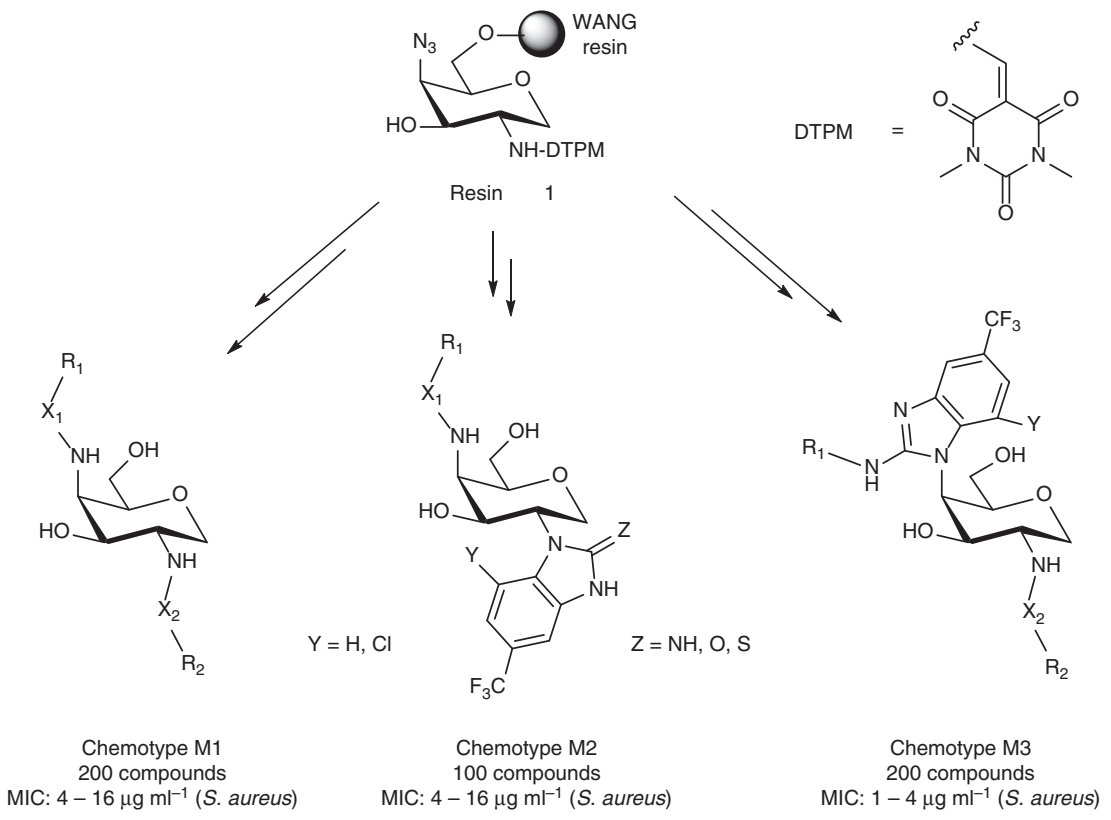

$\mathrm{R}_{1}$

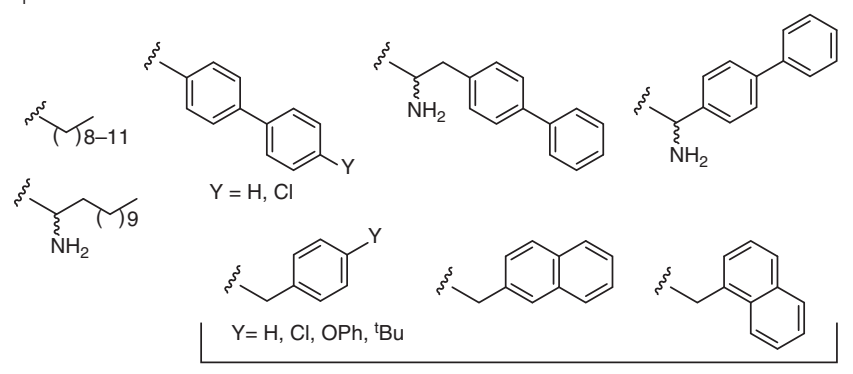

$\mathrm{R}_{2}$

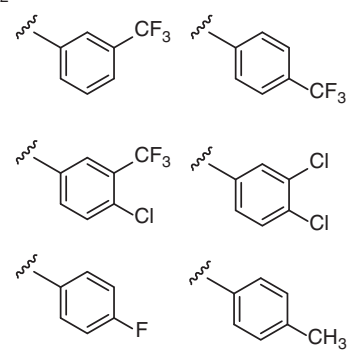

Chemotype M3 only

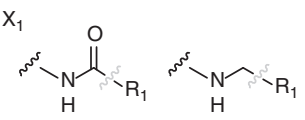

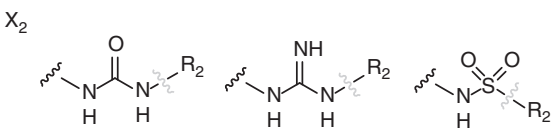

Figure 3 | Design of monosaccharide libraries. The figure illustrates the common starting building block, the three different chemotypes (M1, M2 and M3) and corresponding diversification at each substitution point.

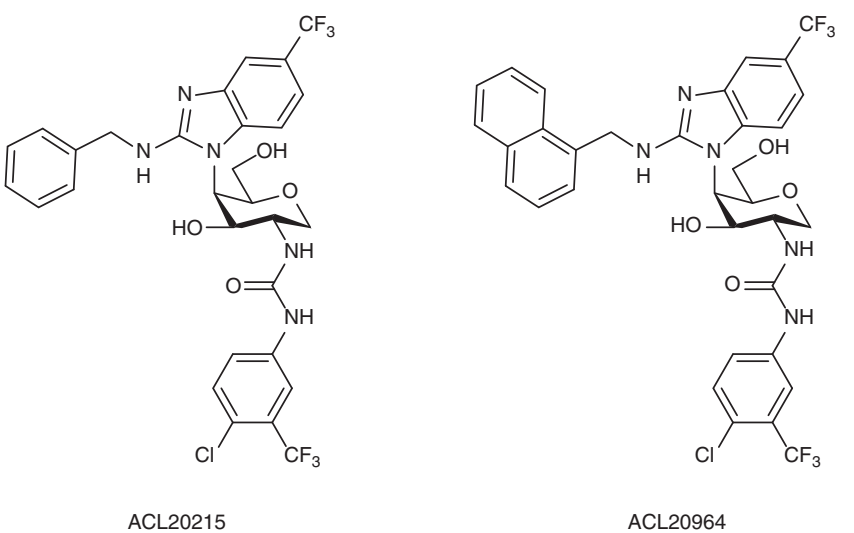

Figure 4 | Structures of ACL20215 and ACL20965. ACL20215 and ACL20965 are two of the most active monosaccharide compounds.

Evaluation of mode of action. To elucidate the mode of action of the inhibitors, we conducted various GT enzyme inhibition assays. We first examined the inhibitory effect of the compounds in a bacterial membrane environment, comparing ACL20215 and
ACL20964 in an in vitro assay for bacterial PG biosynthesis, using crude Bacillus megaterium membrane preparations. This assay monitors $\left[{ }^{14} \mathrm{C}\right] \mathrm{UDP}-\mathrm{GlcNAc}$ incorporation into lipid II and mature PG, in the presence of different concentrations of antibiotics ${ }^{39,40}$. Owing to the sequential nature of the glycosyltransfer and transpeptidation, it is not possible to determine at which step PG biosynthesis is blocked in this assay. The low concentration of lipid II can be detected by thin-layer chromatography (TLC) separation and subsequent phosphorimaging of pre-solubilized membranes, which was incubated with the cytoplasmic PG precursors UDP-MurNAcpentapeptide and UDP- $\left[{ }^{14} \mathrm{C}\right] \mathrm{GlcNAc}{ }^{41,42}$. As shown in Fig. 5 (and Supplementary Table 2 and Fig. 21), both ACL20215 and ACL20964 caused an inhibition of mature PG production at a concentration of $200 \mu \mathrm{g} \mathrm{ml}^{-1}$, to a similar extent as the controls, vancomycin and moenomycin A. Both inhibitors also caused an accumulation of lipid II, although to a lesser extent compared with vancomycin or moenomycin $\mathrm{A}$.

Membrane-disruption experiments were performed using S. aureus (ATCC 25923) in combination with membrane potential-sensitive cyanine dye $\operatorname{diSC}_{3} 5$ (ref. 43). Neither compounds showed membrane disruption (Supplementary 


\section{Table 1 | In vitro activity data of ACL20215 and ACL20964.}

\begin{tabular}{|c|c|c|c|c|c|}
\hline Organism & Strain/type & Vancomycin & Moenomycin A & ACL20215 & ACL20964 \\
\hline \multicolumn{6}{|l|}{$\overline{M I C}\left(\mu g \mathrm{ml}^{-1}\right)$} \\
\hline \multirow{5}{*}{ S. aureus } & MSSA, ATCC 25923 & 1 & & 4 & 4 \\
\hline & MRSA, ATCC 43300 & 1 & 4 & 4 & 8 \\
\hline & NRS 17-GISA & 8 & $16-32$ & 8 & 32 \\
\hline & NRS 1-GISA & 4 & 1 & 4 & 16 \\
\hline & VRS 1 & $>64$ & 8 & 4 & 8 \\
\hline E. faecium & VanA, ATCC 51559 & $>64$ & 32 & 8 & $>64$ \\
\hline \multirow{2}{*}{ E. faecalis } & ATCC 29212 & & & 4 & 8 \\
\hline & VanA, ci & $>64$ & $>64$ & 8 & 64 \\
\hline S. pneumoniae & MDR, ATCC 700677 & 2 & $8-16$ & 4 & $8-16$ \\
\hline E. coli & ATCC 25922 & $>64$ & $>64$ & $>64$ & $>64$ \\
\hline \multicolumn{6}{|l|}{ Mutation frequency } \\
\hline S. aureus (at $4 \times M I C$ ) & ATCC 13709 & & & $2.5 \times 10^{-10}$ & \\
\hline
\end{tabular}

a

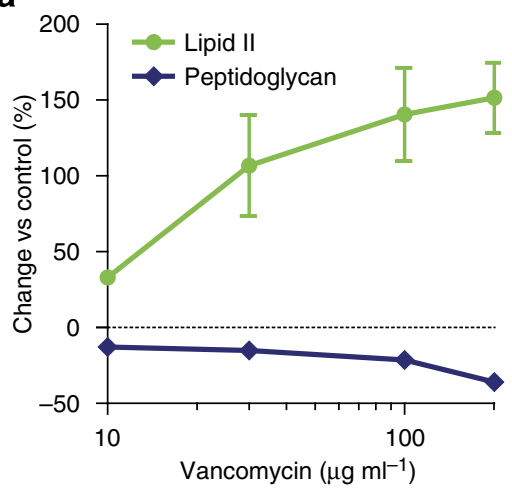

C

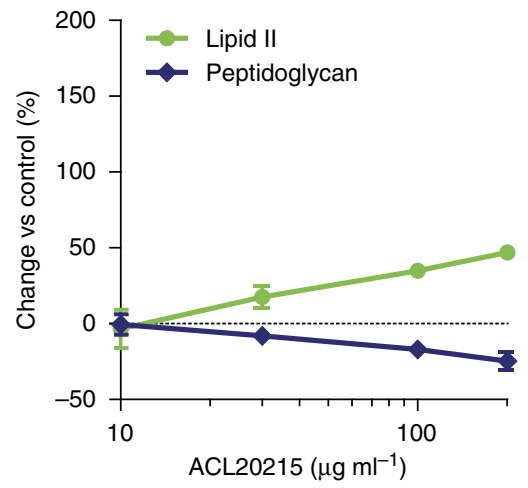

b

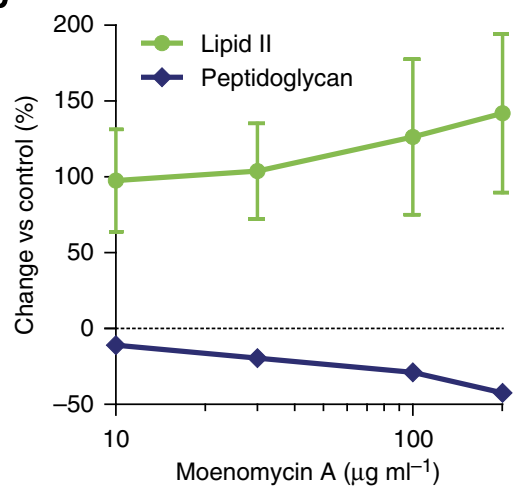

d

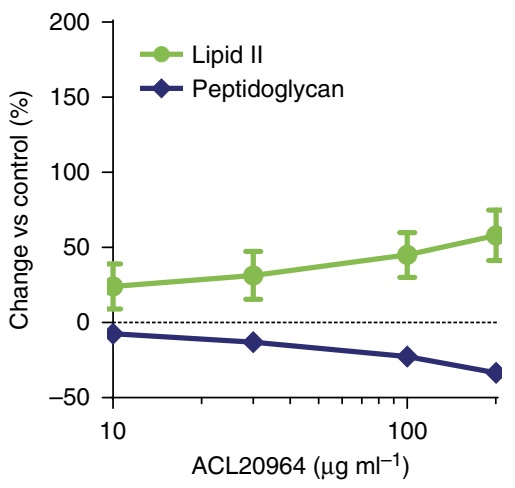

Figure 5 | Inhibition of PG synthesis. The inhibitory effect in bacterial PG biosynthesis within a crude $B$. megaterium membrane is shown for (a) vancomycin, (b) moenomycin A, (c) ACL20215 and (d) ACL20964, showing the relative change of lipid II and PG isolated from the crude membrane by TLC, after $3 \mathrm{~h}$, compared with non-antibiotic treatment. Error bars show s.d. for $n=3$. 

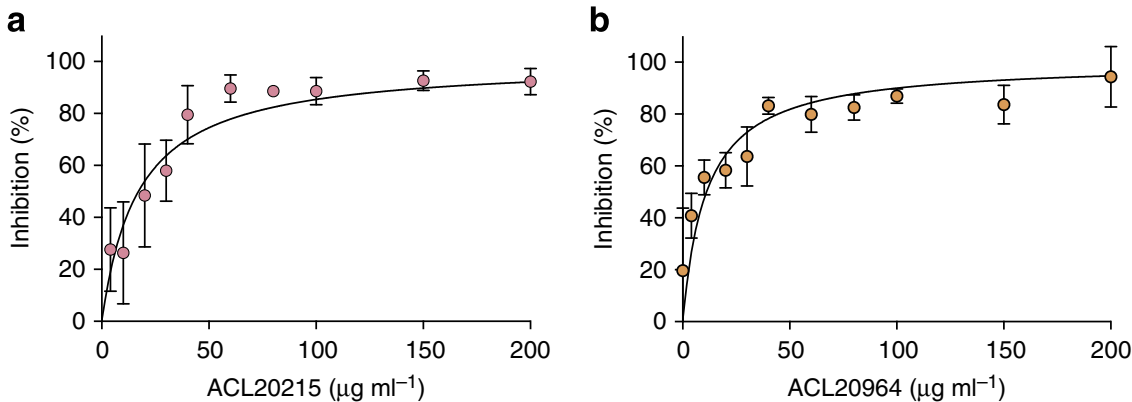

Figure 6 | Inhibition of glycosyltransferase. The inhibition of MGT from S. aureus is shown for ACL20215 (a) and ACL20964 (b), by measuring the transformation rate of fluorescent lipid II analogue and comparing it with the maximum inhibitory effect of moenomycin $\mathrm{A}$ at $50 \mu \mathrm{M}$ or $79.2 \mu \mathrm{g} \mathrm{ml}^{-1}$. Error bars show s.d. for $n=4$.

Fig. 22) compared with a positive control Citropin 1.1 (refs 44-46), which suggested that the GT inhibitors disrupt PG biosynthesis without disrupting the cell membrane.

We then monitored the transformation of fluorescent NBD-lipid II by two different GT enzymes, PBP1 from Clostridium difficile and MGT from $S$. aureus. The single concentration test at $200 \mu \mathrm{g} \mathrm{ml}^{-1}$ revealed that both inhibitors showed an inhibitory effect against MGT S. aureus, while showing only moderate effect against PBP1 C. difficile (Supplementary Fig. 23). Confirmative dose-response assays were subsequently conducted with continuous fluorescent activity assay using a dansyl-labelled, lysine-lipid II substrate ${ }^{47}$. The assay revealed that both ACL20215 and ACL20964 were able to inhibit MGT from $S$. aureus with an $\mathrm{IC}_{50}$ of 17 and $11 \mu \mathrm{g} \mathrm{ml}^{-1}$, respectively (Fig. 6). In the same assay, moenomycin $\mathrm{A}$ was used as positive control showing an $\mathrm{IC}_{50}$ of $5 \mu \mathrm{M}$ or $8 \mu \mathrm{g} \mathrm{ml}^{-1}$.

Virtual docking. Several crystal structures of GT domains have been reported for Gram-positive (MGT ${ }^{48,49}$ and PBP2 (refs 50,51) from S. aureus) and Gram-negative bacteria (PBP1 (ref. 52) from E. coli and $\mathrm{PGT}^{11,53}$ from Aquifex aeolicus), showing a high structural similarity between the difference species. One main feature of the structures is a binding site loop (MGT S. aureus $\mathrm{Phe}_{120}-\mathrm{Gly}_{130}$; PBP2 S. aureus $\left.\mathrm{Gly}_{134}-\mathrm{Gly}_{145}\right)^{54}$ located between the donor-binding site, occupied by moenomycin, and the acceptor binding site occupied by the incoming lipid II molecule. This binding site loop is highly flexibly and partly disordered in most of the crystal structures (see Supplementary Table 3). Even when the loop is resolved, it can occupy different conformations, either separating the donor from the acceptor sites or opening a groove between the sites (see Supplementary Fig. 24 and Supplementary Note 1). We have carried out in silico virtual docking with the monosaccharides ACL20215 and ACL20964, choosing the receptor model (and loop conformation), which best reproduced the binding orientation of moenomycin. A receptor model based on the crystal structure of MGT from $S$. aureus with a loop conformation blocking the access to the acceptor site, $3 \mathrm{HZS}^{48}$, was thereby selected (see Supplementary Fig. 25). As shown in Fig. 7, the benzimidazole group of both inhibitors was located similarly to portion $G$ of moenomycin, with one of the other hydrophobic groups located in the donor-binding site (similar to ring $\mathrm{E}$ of moenomycin), and the other was located towards the acceptor site not occupied by moenomycin. While the virtual docking experiments were able to reproduce the binding orientation of moenomycin, a degree of uncertainty remained due to the flexibility of the binding site loop (Fig. 7), and its ability to adopt different conformations depending on the ligand 49 . However, the docking experiments clearly indicated the

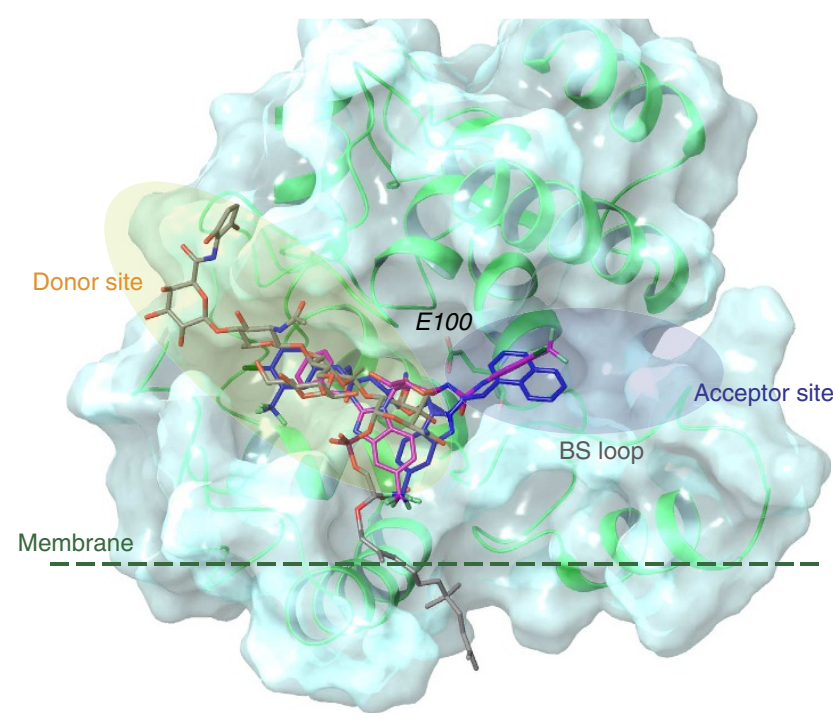

Figure 7 | Virtual docking studies of ACL20215 and ACL20215. The virtual docking poses are shown for ACL20215 (pink) and ACL20964 (blue) within the GT domain of MGT S. aureus ( $\mathrm{pdb}$ : $3 \mathrm{HZS}^{48}$ ) shown as ribbon (green) and surface representation. Binding orientation of moenomycin is shown as found in the corresponding crystal structure (grey). The structure illustrates that both inhibitors are able to occupy the donor, as well as part of the acceptor sites. The dotted line is illustrating the suggested membrane interface ${ }^{49,50}$. BS loop marks the region of the binding site loop with high conformational variation or disorder in the different crystal structure, while E100 marks the active site residue $\mathrm{Glu}_{100}$.

potential of the inhibitors to extend to the acceptor binding site not occupied by moenomycin.

In vivo studies. ACL20215 testing with in vitro metabolic stability assays showed no degradation of the compound using both human and mouse liver microsomes. The in vivo pharmacokinetic properties of ACL20215 and ACL20964 were investigated using intravenous (i.v.) administration at $3.5 \mathrm{mg} \mathrm{kg}^{-1}$ to male rats (Table 2 and Supplementary Table 4). Both compounds had a high apparent half-life $\left(t_{1 / 2}\right)$ of 27.2 and $33.8 \mathrm{~h}$, respectively. They also showed a very high volume of distribution $\left(V_{\mathrm{D}}\right)$ and a high clearance $\left(\mathrm{Cl}_{\text {total }}\right)$. No urinary excretion was detected for either compound, and no metabolites were observed in plasma. The maximum tolerated dose for both compounds (see Supplementary methods) was determined following intraperitoneal (i.p.) administration of the compounds to mice, and showed good tolerance up to $60 \mathrm{mg} \mathrm{kg}^{-1}$, with no mortality up to $100 \mathrm{mg} \mathrm{kg}^{-1}$. Both compounds induced some minor changes to central/ 
Table 2 | Pharmacokinetic properties and in vivo efficacy of ACL20215 and ACL20964.

ACL20215

Pharmacokinetic properties

Metabolic stability (in vitro)

Rat (i.v.)

Dose $\left(\mathrm{mg} \mathrm{kg}^{-1}\right)$

$t_{1 / 2}(h)$

Plasma Cl total $\left(\mathrm{ml} \mathrm{min}^{-1} \mathrm{~kg}^{-1}\right)$

Blood $\mathrm{Cl}_{\text {total }}\left(\mathrm{ml} \mathrm{min} \mathrm{mi}^{-1} \mathrm{~kg}^{-1}\right)$

$V_{\mathrm{Z}}\left(\mathrm{I} \mathrm{kg}^{-1}\right)$

Mice (i.p.)

MTD (mg kg $\left.{ }^{-1}\right)$

In vivo efficacy

Mouse (i.p.)

Survival 7 days (\%)

Mouse (i.v.)

Survival 7 days (\%)

Mouse (mastitis)

$E D_{\text {2logc.fu. }}$ ( $\mu$ g per gland)

$\mathrm{ED}_{4 \log \text { c.f.u. }}$ ( $\mu \mathrm{g}$ per gland)

$\mathrm{PD}_{50}$ ( $\mu$ g per gland)

$\mathrm{PD}_{100}$ ( $\mu \mathrm{g}$ per gland)
No degradation

3.5

27.2

42.1

48.9

97.2

100

100

10

730

1,400

$>1,000$

$>1,000$
ACL20964

ND

3.5

33.8

17.9

21.5

53.0

100

100

10

510

770

$800-1,000$

$>1,000$

$\mathrm{Cl}$, clearance; $\mathrm{ED}_{2 \log \text {.f.fu, }}$ effective dose to reduce bacterial load by $2 \times \log \left(\right.$ c.f.u.); $\mathrm{ED}_{4 \operatorname{logcf.u.}}$ effective dose to reduce bacterial load by $4 \times \log ($ c.f.u.); i.p., intraperitoneal injection; i.v., intravenous injection; MTD, maximal tolerated dose; $N D$, not determined; $P_{50}, 50 \%$ protective dose; $P_{100}, 100 \%$ protective dose; $t_{1 / 2}$, half-life; $V_{Z_{2}}$, volume of distribution.

autonomic responses at the higher dose of $100 \mathrm{mg} \mathrm{kg}^{-1}$. No adverse effects were observed in a single-dose study $\left(4 \mathrm{mg} \mathrm{kg}^{-1}\right)$ following i.v. administration.

ACL20215 and ACL20964 were subsequently tested in a mouse model of septicemia, using 10 male CD-1 (Crl.)-derived mice, inoculated i.p. with a $\mathrm{LD}_{90-100}$ of $S$. aureus (Smith; $3.7 \times 10^{5}$ c.f.u. per mouse). Both compounds administered i.p. $10 \mathrm{~min}$ after inoculation at $50 \mathrm{mg} \mathrm{kg}^{-1}$ resulted in $100 \%$ survival rate after 7 days. However, same studies with i.v. administration of the compounds ( $4 \mathrm{mg} \mathrm{kg}^{-1}, 10 \mathrm{~min}$ after inoculation) showed no antibacterial effect, resulting only in a $10 \%$ survival rate, compared with $90 \%$ for ampicillin $\left(0.1 \mathrm{mg} \mathrm{kg}^{-1}\right)$. The lack of efficacy following i.v. administration is most likely due to a lower dose ( $4 \mathrm{mg} \mathrm{kg}^{-1}$, limited by solubility) combined with the high volume of distribution and serum-binding properties of the compounds, which effectively lowers the free drug concentration at the site of infection. When a higher dose ( $50 \mathrm{mg} \mathrm{kg}^{-1}$ as a suspension) was administered i.p. at the site of infection, the high local concentration of the drug ensures effective clearance of the bacterial infection. Further optimization of compound properties, dose or formulation is required for parenteral administration.

Additional in vivo studies were conducted with ACL20215 and ACL20964 using a mouse mammary gland infection (mastitis) model with intraductal inoculation of S. aureus (Newbould 305, ATCC 29740). Each compound was instilled at different doses into the teat canal of both contralateral glands from the fourth mammary gland pair of lactating mice at $4 \mathrm{~h}$ after bacterial inoculation. Mice were killed at $14 \mathrm{~h}$ post infection and both glands were analyzed for c.f.u. counts (Fig. 8, Table 2 and Supplementary Tables 5 and 6). The effective dose to reduce the bacterial load by $2 \times \log$ (c.f.u.) $\left(\mathrm{ED}_{2 \log }\right)$ were 730 and $510 \mu \mathrm{g}$ per gland, for ACL20215 and ACL20964, respectively, indicating that both compounds cleared $99 \%$ of the staphylococci from the infected mammary gland at a moderate dose. Similarly, the protective doses to clear all bacteria in $50 \%\left(\mathrm{PD}_{50}\right)$ and $100 \%$ $\left(\mathrm{PD}_{100}\right)$ of the glands, respectively, indicated that a high dose of ACL20964 very efficiently cleared S. aureus from the infected glands (Table 2). In contrast, no PD values could be determined for ACL20215 as the latter compound was unable to eradicate all bacteria in 50 or $100 \%$ of the glands in the analyzed doses to at least the detection limit of the assay.

\section{Discussion}

Using moenomycin A and previously reported GT inhibitors ${ }^{27,28}$, we designed and synthesized a small library of disaccharide-based compounds with a smaller, more drug-like, hydrophobic tail ${ }^{29}$. These compounds (such as ACL19378) showed good in vitro antibacterial activity but had unfavourable physicochemical properties that limited their in vivo application. Nevertheless, this set of active compounds gave valuable structure-activity relationship information, which was used to design libraries of compounds based on a smaller monosaccharide scaffold ${ }^{37}$. This strategy also reduced compound hydrophobicity and chemical complexity, enabling the synthesis of the first reported direct GT inhibitors with in vivo efficacy against bacteria.

A reductionist approach, moving from disaccharide mimics of the moenomycin EFG fragment to a smaller monosaccharide scaffold, maintains the key pyranose scaffold and the substitution pattern derived from the disaccharide actives. Chemical chirality inherent in the pyranose scaffold ensures a rigid threedimensional positioning of substituents that is maintained in the series. Second, the solid-phase synthetic method allowed us to make substantial libraries of chemotypes designed to mimic the disaccharide series. In this way, we identified a series of compounds, corresponding to the amino-benzimidazole chemotype, which showed clear antibacterial activity against a range of drug-resistant Gram-positive bacteria. While the cell-based activity suggests a preference for more hydrophobic substituents, some structural variations are not reflected in their activity, such as the difference in activity between a 2- and 1-naphthyl group and the lack of activity of the corresponding biphenyl compound.

The two most promising compounds from this monosaccharide library, that is, ACL20215 and ACL20964, showed good in vitro antibacterial activity against a range of Gram-positive bacteria, including those resistant to common antibiotics, that is, MRSA, GISA and VanA enterococci. PG biosynthesis assay data, taken together, suggests that both compounds trigger an accumulation of lipid II and a decrease of mature PG, as is the 


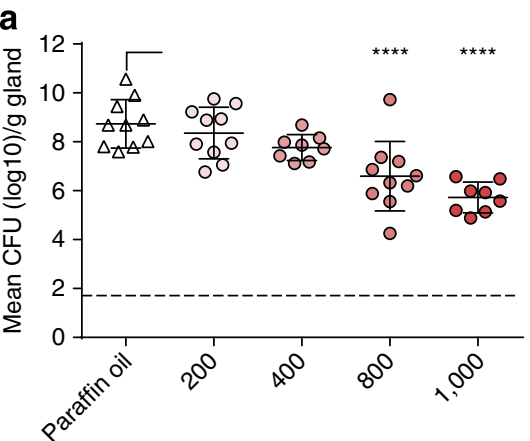

ACL20215 ( $\mu$ g per gland)

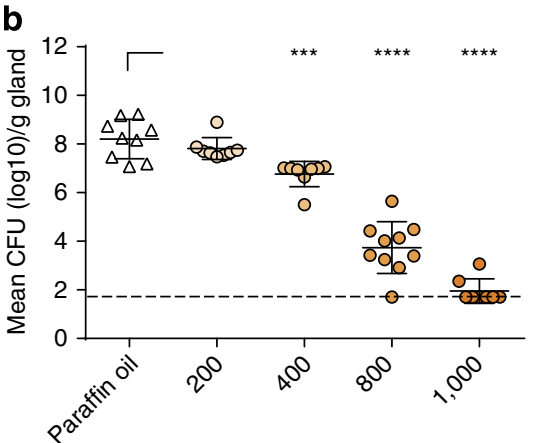

ACL20964 ( $\mu$ g per gland)

Figure 8 | In vivo efficacy in mastitis mouse model. S. aureus c.f.u. counts (c.f.u. $\mathrm{g}^{-1}$ gland) at $14 \mathrm{~h}$ post treatment in infected mouse mammary glands treated with increasing doses of ACL20215 (a) and ACL20964 (b). Significance compared with control (paraffin oil) are given as $P<0.001\left({ }^{\star \star \star}\right)$ and $\left.P<0.0001{ }^{(\star \star \star}\right)$, calculated by one-way analysis of variance followed by Holm-Sidak post hoc test. Dashed line represents the detection limit at 1.7 $\log _{10}$ c.f.u. Data values are given in Supplementary Table 5.

case for moenomycin A. Compounds can inhibit the function of GT with $\mathrm{IC}_{50}$ values similar to that determined for moenomycin. The virtual docking experiment suggest that the compounds are able to bind in the catalytic site of the GT by occupying part of the donor lipid II-binding site (similar to moenomycin A) as well as part of the acceptor lipid II-binding site (not occupied by moenomycin A).

Both hit compounds can be tolerated in mice up to a dose of $100 \mathrm{mg} \mathrm{kg}^{-1}$, while showing good metabolic stability in rats. Even though the library design aimed to reduce the lipophilicity, it is apparent that GT inhibitory compounds require a certain degree of hydrophobicity to be active in vitro and in vivo. The monosaccharide scaffold is an excellent scaffold for drug design, as it is able to present various substituents or binding elements (in this case, three hydrophobic elements) in diverse spatial orientation using up to five chiral attachment points ${ }^{38}$. The scaffold is also able to present those substituents in a conformational rigid form, indicated by the fact that both monosaccharide compounds, ACL20215 and ACL20964, existed as two atropisomers ${ }^{55,56}$ (see Supplementary Fig. 1 and Supplementary Note 1), conformational restricted isomers or rotamers, which would not occur if the carbohydrate scaffold itself was flexible. Virtual docking experiments show both atropisomers among the top ranked poses. It is reasonable to assume that one isomer will be the preferred binding partner for the GT active site, but our in silico and in vitro experiments were unable to distinguish them.

The membrane-associated nature of the GT enzyme and the hydrophobicity of its natural substrate lipid II necessitates a certain degree of lipophilicity for a compound with an inhibitory effect. While serum binding could not be eliminated in this pilot series, ACL20215 and ACL20964 showed in vivo efficacy without toxicity. GT inhibition hence remains a very attractive drug discovery target ${ }^{3}$, as the current inhibitor moenomycin shows extremely low induction of antibiotic resistance ${ }^{14,15}$, and also inhibits the conjugative transfer of resistance plasmids ${ }^{19,57}$; significant advantages given the current background of increased antimicrobial resistance.

\section{Methods}

Solid-phase synthesis. All monosaccharide compounds were synthesized on solid-phase using an orthogonally protected galactitol-building block attached to WANG resin. The synthesis of ACL20215 and ACL20964 is given in

Supplementary Fig. 9 and below as a representative example.

DTPM removal: the resin was treated with a solution of $5 \%$ hydrazine hydrate in dimethylformamide (DMF; $10 \mathrm{mlg}^{-1}$ of resin), shaken (1 h, RT), drained and washed $(3 \times$ DMF, $3 \times$ DCM, $3 \times$ DMF). Urea formation: the resin was treated with a solution of 4 -chloro-3-trifluoromethyl-phenyl isocyanate $(0.15 \mathrm{M})$ in DMF $\left(10 \mathrm{mlg}^{-1}\right.$ of resin), shaken $(\mathrm{O} / \mathrm{N}, \mathrm{RT})$, drained and washed $(3 \times \mathrm{DMF}, 3 \times \mathrm{DCM})$. The resin was taken up in a solution of sodium methoxide $(0.15 \mathrm{M})$ in $\mathrm{MeOH}$ ( $5 \mathrm{mlg}^{-1}$ of resin) and tetrahydrofuran $\left(20 \mathrm{mlg}^{-1}\right.$ of resin), shaken ( $\left.3 \mathrm{~h}, \mathrm{RT}\right)$, drained and washed $(3 \times$ tetrahydrofuran, $3 \times \mathrm{MeOH}, 3 \times \mathrm{DCM}, 3 \times \mathrm{DMF})$. Azide reduction: the resin was treated with a solution of lithium tert-butoxide $(0.2 \mathrm{M})$ and DL-dithiothreitol (DTT, 0.2 M) in DMF ( $15 \mathrm{mlg}^{-1}$ of resin), shaken $(\mathrm{O} / \mathrm{N}, \mathrm{RT})$, drained and washed $(3 \times \mathrm{DMF}, 3 \times \mathrm{MeOH}, 3 \times \mathrm{DCM}, 3 \times \mathrm{DMF})$.

Formation of the substituted benzimidazoles: the resin was treated with a solution of 4 -fluoro-3-nitro-benzotrifluoride $(0.36 \mathrm{M})$ and DIPEA $(0.36 \mathrm{M})$ in $\operatorname{DMF}\left(10 \mathrm{ml} \mathrm{g}^{-1}\right.$ of resin), and heated at $50^{\circ} \mathrm{C}$. The resin was drained and washed with $(3 \times \mathrm{DMF}, 3 \times \mathrm{DCM}, 3 \times \mathrm{DMF})$. Reduction the nitro group: the resin was treated with a solution of $\mathrm{SnCl}_{2} \cdot 2 \mathrm{H}_{2} \mathrm{O}$ in DMF $\left(2.0 \mathrm{M}, 10 \mathrm{mlg}^{-1}\right.$ of resin), shaken $(\mathrm{O} / \mathrm{N}, \mathrm{RT})$, drained and washed $(3 \times \mathrm{DMF}, 3 \times \mathrm{DMF} / \mathrm{MeOH} 1: 1,3 \times \mathrm{DCM}$, $3 \times \mathrm{DMF}, 3 \times \mathrm{DMF} / \mathrm{MeOH} 1: 1,3 \times \mathrm{DCM})$.

To form the benzimidazole, the resin was treated with DIPEA $(0.5 \mathrm{M})$ in DCM $\left(10 \mathrm{ml} \mathrm{g}^{-1}\right.$ of resin), shaken $(1 \mathrm{~h}, \mathrm{RT})$, drained and washed $(3 \times \mathrm{DCM})$, followed by a solution of cyanogen bromide $\left(1.0 \mathrm{M}, 10 \mathrm{mlg}^{-1}\right.$ of resin), shaken $(\mathrm{O} / \mathrm{N}, \mathrm{RT})$, drained and washed $(3 \times \mathrm{DCM}, 3 \times \mathrm{MeOH}, 3 \times \mathrm{DCM})$. To alkylate the 2-amine, the resin was treated with a solution of benzyl bromide or 1-(bromomethyl) naphthalene $(0.4 \mathrm{M})$ and DIPEA $(0.8 \mathrm{M})$ in DMF $\left(10 \mathrm{mlg}^{-1}\right.$ of resin), shaken $(\mathrm{O} / \mathrm{N}, \mathrm{RT})$, drained and washed $(3 \times \mathrm{DCM}, 3 \times \mathrm{MeOH}, 3 \times \mathrm{DCM})$.

Cleavage and purification: each resin was treated with 10\% TFA, $20 \%$ triethylsilane in dry DCM $(1.5 \mathrm{ml})$, allowed to stand at RT for $3 \mathrm{~h}$, drained into a test tube and washed $(3 \times \mathrm{DCM})$. The concentrated samples were treated with a solution of saturated ammonia in methanol $(1.0 \mathrm{ml})$ and left to stand at RT for $2 \mathrm{~h}$, and concentrated by vacuum. Crude samples were purified using preparative highperformance liquid chromatography on a C-18 column (water/acetonitrile gradient).

Analytical data for ACL20215. The analytical data for ACL20125 are given as ${ }^{1} \mathrm{H}-\mathrm{NMR}$, temperature dependent ${ }^{1} \mathrm{H}-\mathrm{NMR},{ }^{13} \mathrm{C}-\mathrm{NMR}$, COSY, edCOSY and HMBC NMR spectra in Supplementary Figs. 10-15, respectively. The structure of ACL20215 exists as two distinctive rotamers or conformational isomers that can be detected in NMR experiments. Transition between the two isomers, or atropisomers, can be achieved by heating the sample to $45^{\circ} \mathrm{C}$ (see Supplementary Fig. 11). In silico analysis of the structure and conformation of ACL20125 indicate restricted torsional rotation of the $\mathrm{C}^{4}-\mathrm{N}^{\text {Benzimidazole }}$ bond, due to size of the benzimidazole group. Energy barrier calculation indicate an upper range of 25 $\mathrm{kcal} / \mathrm{mol}$ for this rotational barrier (see Supplementary Fig. 3), which, in relation to other known atropisomers, corresponds to an interconversion rate from a few hours to a few days ${ }^{56}$.

${ }^{1} \mathrm{H}-\mathrm{NMR}(600 \mathrm{MHz}$, dimethylsulphoxide (DMSO)-d6): major rotamer $\delta 9.20$ (br s, $1 \mathrm{H}, 7-\mathrm{NH}), 8.10$ (d, $J=8.0 \mathrm{~Hz}, 1 \mathrm{H}, \mathrm{H}-20), 8.02$ (d, $J=2.2 \mathrm{~Hz}, 1 \mathrm{H}, \mathrm{H}-9), 7.50$ (d, $J=8.9 \mathrm{~Hz}, 1 \mathrm{H}, \mathrm{H}-13$ ), 7.48 (dd, $J=2.2,8.9 \mathrm{~Hz}, 1 \mathrm{H}, \mathrm{H}-12), 7.42$ (s, 1H, H-17), 7.39 (d, $J=7.3 \mathrm{~Hz}, 2 \mathrm{H}, \mathrm{H}-25, \mathrm{H}-29), 7.27$ (dd, $J=7.3,7.3 \mathrm{~Hz}, 2 \mathrm{H}, \mathrm{H}-26, \mathrm{H}-28$ ), 7.22 $(\mathrm{d}, J=8.0 \mathrm{~Hz}, 1 \mathrm{H}, \mathrm{H}-19), 7.19(\mathrm{dd}, J=7.3,7.3 \mathrm{~Hz}, 1 \mathrm{H}, \mathrm{H}-27), 7.14(\mathrm{t}, J=5.8 \mathrm{~Hz}$, $1 \mathrm{H}, 15-\mathrm{NH}), 6.34(\mathrm{~d}, J=6.0 \mathrm{~Hz}, 1 \mathrm{H}, 2-\mathrm{NH}), 5.41$ (d, $J=5.8 \mathrm{~Hz}, 1 \mathrm{H}, 3-\mathrm{OH}), 4.91$ $(\mathrm{m}, 1 \mathrm{H}, \mathrm{H}-4), 4.91(\mathrm{t}, J=5.1 \mathrm{~Hz}, 1 \mathrm{H}, 6-\mathrm{OH}), 4.63(\mathrm{~m}, 2 \mathrm{H}, \mathrm{H}-23), 4.27$ (dd, $J=5.2$, $11.2 \mathrm{~Hz}, 1 \mathrm{H}, \mathrm{H}-1 \beta$ ), 4.00 (m, 2H, H-3, H-5), 3.87 (dddd, $J=5.2,5.8,11.2,11.2 \mathrm{~Hz}$, $1 \mathrm{H}, \mathrm{H}-2), 3.40$ (m, $1 \mathrm{H}, \mathrm{H}-6 \mathrm{a}), 3.39(\mathrm{~m}, 1 \mathrm{H}, \mathrm{H}-1 \alpha), 3.18$ (dd, $J=5.8,5.8,11.2 \mathrm{~Hz}$, $1 \mathrm{H}, \mathrm{H}-6 \mathrm{~b})$; minor rotamer $\delta 9.25$ (br s, $1 \mathrm{H}, 7-\mathrm{NH}), 8.10(\mathrm{~d}, J=2.2 \mathrm{~Hz}, 1 \mathrm{H}, \mathrm{H}-9)$, $7.78(\mathrm{t}, J=5.2 \mathrm{~Hz}, 1 \mathrm{H}, 15-\mathrm{NH}), 7.54(\mathrm{~m}, 2 \mathrm{H}, \mathrm{H}-12, \mathrm{H}-13), 7.54$ (d, J=7.3 Hz, 2H, H-25, H-29), 7.45 (s, 1H, H-17), 7.36 (d, $J=8.0 \mathrm{~Hz}, 1 \mathrm{H}, \mathrm{H}-20), 7.35$ (dd, $J=7.3$, $7.3 \mathrm{~Hz}, 2 \mathrm{H}, \mathrm{H}-26, \mathrm{H}-28$ ), 7.27 (dd, $J=7.3,7.3 \mathrm{~Hz}, 1 \mathrm{H}, \mathrm{H}-27), 7.21$ (d, $J=8.0 \mathrm{~Hz}$, $1 \mathrm{H}, \mathrm{H}-19), 6.36(\mathrm{~d}, J=6.0 \mathrm{~Hz}, 1 \mathrm{H}, 2-\mathrm{NH}), 5.29(\mathrm{~d}, J=6.1 \mathrm{~Hz}, 1 \mathrm{H}, 3-\mathrm{OH}), 5.00(\mathrm{~m}$, $1 \mathrm{H}, \mathrm{H}-4), 4.96(\mathrm{t}, J=5.2 \mathrm{~Hz}, 1 \mathrm{H}, 6-\mathrm{OH}), 4.65(\mathrm{~m}, 1 \mathrm{H}, \mathrm{H}-23 \mathrm{a}), 4.63(\mathrm{~m}, 1 \mathrm{H}, \mathrm{H}-23 \mathrm{~b})$, 4.24 (dddd, $J=5.2,5.8,11.2,11.2 \mathrm{~Hz}, 1 \mathrm{H}, \mathrm{H}-2), 4.16$ (dd, $J=5.2,11.2 \mathrm{~Hz}, 1 \mathrm{H}$, H-1ß), 4.07 (m, 2H, H-3, H-5), 3.48 (ddd, $J=5.2,5.2,11.2 \mathrm{~Hz}, 1 \mathrm{H}, \mathrm{H}-6 \mathrm{a}), 3.39$ 
$(\mathrm{m}, 1 \mathrm{H}, \mathrm{H}-1 \alpha), 3.27(\mathrm{dd}, J=5.8,5.8,11.2 \mathrm{~Hz}, 1 \mathrm{H}, \mathrm{H}-6 \mathrm{~b}) ;{ }^{13} \mathrm{C}-\mathrm{NMR}(150 \mathrm{MHz}$, DMSO-d6): major rotamer $\delta 158.9$ (C-15), 154.9 (C-7), 143.0 (C-16), 140.1 (C-24), 139.9 (C-8), 137.4 (C-21), 131.8 (C-12), 128.0 (C-26, C-28), 126.8 (C-25, C-29), $126.4(\mathrm{C}-27), 125.5(\mathrm{q}, 1 \mathrm{JCF}=271 \mathrm{~Hz}, \mathrm{C}-22), 122.9(\mathrm{q}, 1 \mathrm{JCF}=273 \mathrm{~Hz}, \mathrm{C}-14), 122.6$ $(\mathrm{q}, 2 \mathrm{JCF}=31 \mathrm{~Hz}, \mathrm{C}-10), 122.3(\mathrm{C}-13), 121.5(\mathrm{C}-11), 121.0(\mathrm{q}, 2 \mathrm{JCF}=31 \mathrm{~Hz}, \mathrm{C}-18)$, 116.1 (C-9), 115.0 (C-19), 112.1 (C-20), 111.4 (C-17), 77.7 (C-5), 70.7 (C-3), 68.8 (C-1), 60.3 (C-6), 55.2 (C-4), 48.8 (C-2), 46.0 (C-23); minor rotamer $\delta 155.8$ (C-15), 155.0 (C-7), 142.1 (C-16), 140.9 (C-21), 139.9 (C-8), 139.0 (C-24), 131.9 (C-12), 128.4 (C-26, C-28), 127.5 (C-25, C-29), 127.0 (C-27), 125.5 (q, 1JCF = $271 \mathrm{~Hz}, \mathrm{C}-22), 122.9(\mathrm{q}, 1 \mathrm{JCF}=273 \mathrm{~Hz}, \mathrm{C}-14), 122.6(\mathrm{q}, 2 \mathrm{JCF}=31 \mathrm{~Hz}, \mathrm{C}-10), 122.3$ (C-13), $121.5(\mathrm{C}-11), 121.0(\mathrm{q}, 2 \mathrm{JCF}=31 \mathrm{~Hz}, \mathrm{C}-18), 116.1(\mathrm{C}-9), 115.0(\mathrm{C}-19)$, 109.4 (C-20), 111.1 (C-17), 77.9 (C-5), 70.8 (C-3), 69.0 (C-1), 59.9 (C-6), $56.4(\mathrm{C}-4), 48.5(\mathrm{C}-2), 46.8(\mathrm{C}-23)$; HRESIMS $(\mathrm{m} / \mathrm{z}):[\mathrm{M}+\mathrm{H}]+$ calcd. for $\mathrm{C}_{29} \mathrm{H}_{27} \mathrm{Cl}_{1} \mathrm{~F}_{6} \mathrm{~N}_{5} \mathrm{O}_{4}, 658.1650$; found, 658.1659 .

Analytical data for ACL20964. The analytical data for ACL20964 are given as ${ }^{1} \mathrm{H}-\mathrm{NMR},{ }^{13} \mathrm{C}-\mathrm{NMR}$, COSY, edCOSY and HMBC NMR spectra in Supplementary Figs 16-20, respectively. Similar to ACL20215, ACL20964 exists as two conformational isomer, due to rotational restriction of the $\mathrm{C}^{4}-\mathrm{N}^{\text {Benzimidazole }}$ bond, caused by the large benzimidazole group.

${ }^{1} \mathrm{H}-\mathrm{NMR}(600 \mathrm{MHz}$, DMSO-d6): major rotamer $\delta 9.26$ (br s, $1 \mathrm{H}, 7-\mathrm{NH}), 8.14(\mathrm{~d}$, $J=8.2 \mathrm{~Hz}, 1 \mathrm{H}, \mathrm{H}-32), 8.13(\mathrm{~d}, J=8.2 \mathrm{~Hz}, 1 \mathrm{H}, \mathrm{H}-20), 8.04$ (s, $1 \mathrm{H}, \mathrm{H}-9), 7.94$ $(\mathrm{d}, J=8.2 \mathrm{~Hz}, 1 \mathrm{H}, \mathrm{H}-29), 7.81(\mathrm{~d}, J=8.2 \mathrm{~Hz}, 1 \mathrm{H}, \mathrm{H}-27), 7.63(\mathrm{~d}, J=8.2 \mathrm{~Hz}, 1 \mathrm{H}$, C-25), 7.54 (m, 2H, H-30, H-31), 7.51 (m, 2H, H-12, H-13), 7.42 (s, 1H, H-17), 7.39 (dd, $J=8.2,8.2 \mathrm{~Hz}, 1 \mathrm{H}, \mathrm{H}-26), 7.22(\mathrm{~d}, J=8.2 \mathrm{~Hz}, 1 \mathrm{H}, \mathrm{H}-19), 7.19(\mathrm{t}, J=$ $5.7 \mathrm{~Hz}, 1 \mathrm{H}, 15-\mathrm{NH}), 6.34$ (br s, 1H, 2-NH), 5.47 (br s, 1H, 3-OH), 5.09 (m, 2H, H-23), 4.97 (m, 1H, H-4), 4.95 (br s, $1 \mathrm{H}, 6-\mathrm{OH}), 4.28$ (dd, $J=4.8,11.2 \mathrm{~Hz}, 1 \mathrm{H}, \mathrm{H}-1 \beta), 4.01$ (m, 2H, H-3, H-5), $3.92(\mathrm{~m}, 1 \mathrm{H}, \mathrm{H}-2), 3.45$ (m, 1H, H-6a), 3.39 (m, $1 \mathrm{H}, \mathrm{H}-1 \alpha), 3.23(\mathrm{~m}, 1 \mathrm{H}, \mathrm{H}-6 \mathrm{~b})$; minor rotamer $\delta 9.26(\mathrm{br} \mathrm{s}, 1 \mathrm{H}, 7-\mathrm{NH}), 8.21$ (d, $J=8.2 \mathrm{~Hz}, 1 \mathrm{H}, \mathrm{H}-32$ ), 8.10 (s, $1 \mathrm{H}, \mathrm{H}-9), 7.96$ (d, $J=8.2 \mathrm{~Hz}, 1 \mathrm{H}, \mathrm{H}-29), 7.87$ (d, $J=8.2 \mathrm{~Hz}, 1 \mathrm{H}, \mathrm{H}-27), 7.78(\mathrm{t}, J=5.1 \mathrm{~Hz}, 1 \mathrm{H}, 15-\mathrm{NH}), 7.73(\mathrm{~d}, J=8.2 \mathrm{~Hz}, 1 \mathrm{H}$, C-25), 7.60 (dd, $J=8.2,8.2 \mathrm{~Hz}, \mathrm{H}-31$ ), 7.55 (m, $2 \mathrm{H}, \mathrm{H}-12, \mathrm{H}-13), 7.54$ (m, $1 \mathrm{H}, \mathrm{H}-30)$, 7.47 (s, 1H, H-17), 7.50 (m, 1H, H-26), 7.37 (d, J=8.2 Hz, 1H, H-20), 7.22 (d, $J=8.2 \mathrm{~Hz}, 1 \mathrm{H}, \mathrm{H}-19), 6.36$ (br s, $1 \mathrm{H}, 2-\mathrm{NH}), 5.31$ (br s, $1 \mathrm{H}, 3-\mathrm{OH}), 5.16$ (dd, $J=5.6$, $15.3 \mathrm{~Hz}, 1 \mathrm{H}, \mathrm{H}-23 \mathrm{a}), 5.11$ (dd, $J=4.8,15.3 \mathrm{~Hz}, 1 \mathrm{H}, \mathrm{H}-23 \mathrm{~b}), 5.01$ (m, 1H, H-4), 4.95 (br s, $1 \mathrm{H}, 6-\mathrm{OH}), 4.24(\mathrm{~m}, 1 \mathrm{H}, \mathrm{H}-2), 4.16(\mathrm{dd}, J=5.2,11.2 \mathrm{~Hz}, 1 \mathrm{H}, \mathrm{H}-1 \beta), 4.05(\mathrm{~m}$,

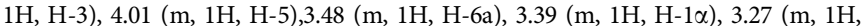
H-6b); ${ }^{13} \mathrm{C}-\mathrm{NMR}$ (150 MHz, DMSO-d6): major rotamer $\delta 158.7$ (C-15), 154.9 (C-7), 143.1 (C-16), 140.0 (C-8), 137.5 (C-21), 134.9 (C-33), 134.2 (C-28), 131.9 (C-12), 130.9 (C-24), 128.5 (C-29), 127.0 (C-27), $126.6(\mathrm{q}, 2 \mathrm{JCF}=31 \mathrm{~Hz}, \mathrm{C}-10), 126.1(\mathrm{C}-31)$, $125.6(\mathrm{C}-30), 125.5(\mathrm{C}-26), 125.4(\mathrm{q}, 1 \mathrm{JCF}=271 \mathrm{~Hz}, \mathrm{C}-22), 124.6(\mathrm{C}-25), 123.4(\mathrm{C}-$ $32), 122.8(\mathrm{q}, 1 \mathrm{JCF}=273 \mathrm{~Hz}, \mathrm{C}-14), 122.3(\mathrm{C}-13), 121.5(\mathrm{C}-11), 121.0(\mathrm{q}$, 2JCF $=31 \mathrm{~Hz}, \mathrm{C}-18), 116.1$ (C-9), 115.0 (C-19), 112.1 (C-20), 111.4 (C-17), 77.6 (C5), 70.7 (C-3), 68.8 (C-1), 60.3 (C-6), 55.1 (C-4), 49.0 (C-2), 44.3 (C-23); minor rotamer $\delta 155.8$ (C-15), 154.9 (C-7), 142.1 (C-16), 140.9 (C-21), 140.0 (C-8), 134.2 (C-33), 133.2 (C-28), 131.8 (C-12), 130.9 (C-24), 128.6 (C-29), 127.7 (C-27), 126.6 (q, $2 J C F=31 \mathrm{~Hz}, \mathrm{C}-10), 126.5(\mathrm{C}-31), 125.8(\mathrm{C}-30), 125.6(\mathrm{C}-26), 125.4(\mathrm{q}$,

$1 \mathrm{JCF}=271 \mathrm{~Hz}, \mathrm{C}-22), 125.4(\mathrm{C}-25), 123.4(\mathrm{C}-32), 122.8(\mathrm{q}, 1 \mathrm{JCF}=273 \mathrm{~Hz}, \mathrm{C}-14)$, $122.3(\mathrm{C}-13), 121.5(\mathrm{C}-11), 121.0(\mathrm{q}, 2 \mathrm{JCF}=31 \mathrm{~Hz}, \mathrm{C}-18), 116.1(\mathrm{C}-9), 115.0(\mathrm{C}-19)$, 111.1 (C-17), 109.5 (C-20), 77.8 (C-5), 70.9 (C-3), 68.5 (C-1), 59.8 (C-6), 56.4 (C-4), 48.5 (C-2), $44.7(\mathrm{C}-23)$; HRESIMS $(\mathrm{m} / \mathrm{z}):[\mathrm{M}+\mathrm{H}]+$ calcd. for $\mathrm{C}_{33} \mathrm{H}_{29} \mathrm{Cl}_{1} \mathrm{~F}_{6} \mathrm{~N}_{5} \mathrm{O}_{4}$, 708.1807; found, 708.1797 .

Virtual docking. The virtual docking of inhibitor and moenomycin structures into the binding site of MGT from S. aureus were done using the software Glide (version 6.5, Schrödinger, LLC, New York, 2014 (ref. 58)) and using several different crystal structures with different binding site loop conformations. In addition, the induced fit protocol in the Schrödinger software package (Induced Fit Docking protocol 2014-4, Glide version 6.5, Prime version 3.7, Schrödinger, $\mathrm{LLC}^{59,60}$ ) was used to allow conformational flexibility of the GT domain. The docking experiments were all done using the standard precision (SP) in Glide and defining a binding site with $13 \AA$ around the crystal structure of moenomycin, large enough to include also the acceptor site which is not occupied by moenomycin. For the structure of moenomycin, a truncated version was used, without the fatty acid chain and only a lactic acid attached to the phosphate group. Models for inhibitors were built in four different conformations, ${ }^{4} \mathrm{C}_{1}$ and ${ }_{1} \mathrm{C}^{4}$ chair conformation for the galactose moiety, and two different orientations for the benzimidazole moiety compared with the galactose ring. All structure models were built using Maestro (version 10.0, Schrödinger, LLC, New York, 2014).

The different approaches, that is, crystal structures and protocols, were validated and the best one selected by comparing the docking orientation of moenomycin with the one found in the crystal structures, by visual inspection. The following models for MGT from $S$ aureus have been used for the docking experiments: $3 \mathrm{HZSm}-3 \mathrm{HZS}^{48}$ changing to wild type, by mutating Asn 100 to Asp, $3 \mathrm{VMRm}-3 \mathrm{VMR}^{49}$ modelling the missing loop residues (2 residues) with loop search, 3NB6sa-Homology model of MGT S. aureus sequence using 3NB6 (ref. 11) (PGT from A. aeolicus) with complete loop as template, 3VMSm-3VMS ${ }^{49}$ modelling missing loop (7 residues) using the loop in 3NB6 (ref. 11) as template.

From these receptor models, $3 \mathrm{HZSm}$ was able to reproduce the binding orientation of moenomycin A as found in the crystal structure (see Supplementary
Fig. 25; a, green: crystal structure; grey; docked structure). The 3VMRm model produced similar orientations for moenomycin but with different orientation of the $\mathrm{D}$ ring. In 3NB6sa model, moenomycin was binding in the same binding pocket but its orientation was always different, with phosphoglycerate (G) portion of the molecule facing either to the solvent, the donor or acceptor binding site. In the 3VMSm model, which has the most open groove between the donor and acceptor site, moenomycin was actually oriented partly across the acceptor binding site. Induced fit protocol on those models did not produce better moenomycin binding orientations compared with the standard docking protocol.

In vitro PG biosynthesis. The cell-free particulate fraction of B. megaterium KM (ATCC13632), capable of catalysing the polymerization of PG from UPD-linked precursors was performed as described previously ${ }^{61}$. B. megaterium was grown in standard medium, harvested and washed with Tris-buffer by centrifugation. Resuspended bacteria were subjected to three freeze/thaw cycles $(5 \mathrm{~min}$ dry ice, followed by $10 \mathrm{~min}$ at RT), homogenized by the glass homogenizer and centrifuged all at $4{ }^{\circ} \mathrm{C}$, leaving most of the cell wall in the pellet. Resuspended pellet was combined with UDP- $N$-acetylmuramyl-pentapeptide, $\left[{ }^{14} \mathrm{C}\right] \mathrm{UDP}-\mathrm{N}$ acetylglucosamine and individual compounds or antibiotics (that is, vancomycin hydrochloride or moenomycin A), and incubated at for $3 \mathrm{~h}$ at RT, placed in a boiling water bath for $3 \mathrm{~min}$ to inactivate enzymes and to prevent any further lipid II transformation, and analysed by TLC on silica gel plates. After separation, plates were dried, exposed to phosphorimaging screen (1 week), scanned by Typhoon 8600 calculating the integrated density value of each band on silica gel. Changes of PG or lipid II were calculated as a percentage from negative control (for more details see Supplementary Methods).

Inhibition of glycosyltransferase. Inhibition of glycosyltransferase was measured using a fluorescence detection method ${ }^{62}$ by adding $1 \mu \mathrm{M}$ S. aureus MGT to $1.45 \mu \mathrm{M}$ fluorescent dansyl-Lys Lipid II and different concentration of inhibitors, all in a buffer of $50 \mathrm{mM}$ Tris pH 8 containing $10 \mathrm{mM} \mathrm{MnCl}_{2}, 0.08 \%$ (v/v) decyl PEG, $10 \%$ (v/v) DMSO, $100 \mathrm{\mu g} \mathrm{ml}^{-1}$ hen egg-white lysozyme, in 96-well microtiter plates. Initial rates were measured as a decrease in fluorescence (ex/em: 340/ $521 \mathrm{~nm})$ and calculated as a percentage compared with no inhibitor as negative control ( $0 \%$ of rate inhibition) and moenomycin A (Sigma, Cat. no.: 32404) as positive control (100\% of rate inhibition). The data were fitted to a simple saturation model of inhibitor binding to a single site, from which $\mathrm{IC}_{50}$ values were extracted. Moenomycin A showed an $\mathrm{IC}_{50}$ of $5 \mu \mathrm{M}$ in this assay.

Minimal inhibitory concentration (MIC) determination. The compounds along with standard antibiotics were serially diluted twofold across the wells of 96-well standard polystyrene non-treated plates (Corning 3370). Compounds and standard antibiotic controls ranged from $1.28 \mathrm{mg} \mathrm{ml}^{-1}$ to $0.06 \mu \mathrm{g} \mathrm{ml}^{-1}$ with final volumes of $50 \mu \mathrm{l}$ per well. Bacteria were cultured in Brain-Heart Infusion (Bacto laboratories, Cat. no. CM1135B) at $37^{\circ} \mathrm{C}$ overnight. A sample of each culture was then diluted 40 -fold in fresh brain-heart infusion broth and incubated at $37^{\circ} \mathrm{C}$ for $2-3 \mathrm{~h}$. The resultant mid-log phase cultures were diluted to $5 \times 10^{5}$ c.f.u. $\mathrm{ml}^{-1}$ then $50 \mu \mathrm{l}$ was added to each well of the compound-containing 96 -well plates giving a final compound concentration range of $64 \mu \mathrm{g} \mathrm{ml}{ }^{-1}$ to $0.03 \mu \mathrm{g} \mathrm{ml}^{-1}$ in $2.5 \times$ $10^{5}$ c.f.u. ml ${ }^{-1}$. All the plates were covered and incubated at $37^{\circ} \mathrm{C}$ for $24 \mathrm{~h}$. MICs were determined visually as the lowest concentration showing no visible growth.

Antibiotic control compound vancomycin (Sigma, Cat. no.: 861987) was prepared as water solution, while moenomycin A (Sigma, Cat. no.: 32404) was dissolved in DMSO and $20 \mathrm{mM}$ ammonium acetate, due to solubility issues. The average MIC for moenomycin for S. aureus was, however, within the range of recent literature ${ }^{35}$.

In vivo mouse mammary gland infection model. For the infection of the mice, S. aureus Newbould 305 (ATCC 29740) isolated from a clinical mastitis cases ${ }^{63}$ was used and prepared. The procedure for mouse mammary gland infection has been recently described ${ }^{64}$. CD-1 lactating mice were utilized 12-14 days after giving birth, with pups weaned $1-2 \mathrm{~h}$ before bacterial inoculation of the mammary glands. Inoculation of both left (L4) and right (R4) glands of the fourth abdominal mammary gland pair of anesthetized mice with 150 c.f.u. of S. aureus, was done using 32-gauge syringes (blunt needle). The antimicrobial formulation was instilled into the mammary gland of anesthetized mice at $4 \mathrm{~h}$ after bacterial inoculation, followed by i.p. administration of postoperative analgesic Buprecare. Mice were killed $14 \mathrm{~h}$ post treatment, mammary glands (two per mouse) were harvested, weighed and homogenized. Bacterial c.f.u. counts were obtained after quantification of serial logarithmic dilutions of mammary gland homogenates on TSA. The detection limit (DL) was $1.7 \log _{10}$ c.f.u. ${ }^{-1}$ gland weight (for more details see Supplementary Methods). The animal experiments were approved by the Ethical Committee of the Faculty of Veterinary Medicine, Ghent University (EC2009/133).

\section{References}

1. Derouaux, A., Sauvage, E. \& Terrak, M. Peptidoglycan glycosyltransferase substrate mimics as templates for the design of new antibacterial drugs. Front. Immunol. 4, 78 (2013). 
2. Bouhss, A., Trunkfield, A. E., Bugg, T. D. \& Mengin-Lecreulx, D. The biosynthesis of peptidoglycan lipid-linked intermediates. FEMS Microbiol. Rev. 32, 208-233 (2008).

3. Galley, N. F., O’Reilly, A. M. \& Roper, D. I. Prospects for novel inhibitors of peptidoglycan transglycosylases. Bioorg. Chem. 55, 16-26 (2014).

4. Goffin, C. \& Ghuysen, J. M. Multimodular penicillin-binding proteins: an enigmatic family of orthologs and paralogs. Microbiol. Mol. Biol. Rev. 62, 1079-1093 (1998).

5. Coutinho, P. M., Deleury, E., Davies, G. J. \& Henrissat, B. An evolving hierarchical family classification for glycosyltransferases. J. Mol. Biol. 328, 307-317 (2003).

6. Ling, L. L. et al. A new antibiotic kills pathogens without detectable resistance. Nature 517, 455-459 (2015).

7. Arias, C. A. \& Murray, B. E. The rise of the Enterococcus: beyond vancomycin resistance. Nat. Rev. Microbiol. 10, 266-278 (2012).

8. Gualerzi, C. O., Brandi, L., Fabbretti, A. \& Pon, C. L. Antibiotics: Targets, mechanisms and resistance (John Wiley \& Sons, 2013).

9. Gharsallaoui, A., Oulahal, N., Joly, C. \& Degraeve, P. Nisin as a food preservative: part 1: physicochemical properties, antimicrobial activity, and main uses. Crit. Rev. Food Sci. Nutr. http://www.tandfonline.com/doi/abs/ 10.1080/10408398.2013.763766 (2015).

10. Ostash, B. \& Walker, S. Moenomycin family antibiotics: chemical synthesis, biosynthesis, and biological activity. Nat. Prod. Rep. 27, 1594-1617 (2010).

11. Fuse, S. et al. Functional and structural analysis of a key region of the cell wall inhibitor moenomycin. ACS Chem. Biol. 5, 701-711 (2010).

12. O'Brien, T. F. et al. Facts about antibiotics in animals and their impact on resistance. Clin. Infect. Dis. 34, S71-S144 (2002).

13. Silbergeld, E. K., Graham, J. \& Price, L. B. Industrial food animal production, antimicrobial resistance, and human health. Annu. Rev. Public Health 29, 151-169 (2008)

14. Butaye, P., Devriese, L. A. \& Haesebrouck, F. Differences in antibiotic resistance patterns of Enterococcus faecalis and Enterococcus faecium strains isolated from farm and pet animals. Antimicrob. Agents Chemother. 45, 1374-1378 (2001).

15. Hentschel, S., Kusch, D. \& Sinell, H. J. Staphylococcus aureus in poultry-biochemical characteristics, antibiotic resistance and phage pattern. Zentralbl. Bakteriol. [B] 168, 546-561 (1979).

16. Rebets, Y. et al. Moenomycin resistance mutations in Staphylococcus aureus reduce peptidoglycan chain length and cause aberrant cell division. ACS Chem. Biol. 9, 459-467 (2014).

17. Huber, G. Mechanism of action of antibacterial agents. Moenomycin and related phosphorus-containing antibiotics. Antibiotics 5, 135-153 (1979).

18. Butaye, P., Devriese, L. A. \& Haesebrouck, F. Antimicrobial growth promoters used in animal feed: effects of less well known antibiotics on gram-positive bacteria. Clin. Microbiol. Rev. 16, 175-188 (2003).

19. Pfaller, M. A. Flavophospholipol use in animals: positive implications for antimicrobial resistance based on its microbiologic properties. Diagn. Microbiol. Infect. Dis. 56, 115-121 (2006).

20. Makitrynskyy, R. et al. Genetic factors that influence moenomycin production in streptomycetes. J. Ind. Microbiol. Biotechnol. 37, 559-566 (2010).

21. Ostash, B. et al. Complete characterization of the seventeen step moenomycin biosynthetic pathway. Biochemistry 48, 8830-8841 (2009).

22. Ostash, B., Doud, E. \& Fedorenko, V. The molecular biology of moenomycins: towards novel antibiotics based on inhibition of bacterial peptidoglycan glycosyltransferases. Biol. Chem. 391, 499-504 (2010).

23. Van Heijenoort, J. Formation of the glycan chains in the synthesis of bacterial peptidoglycan. Glycobiology 11, 25R-36R (2001).

24. Schneider, T. \& Sahl, H. G. An oldie but a goodie - cell wall biosynthesis as antibiotic target pathway. Int. J. Med. Microbiol. 300, 161-169 (2010).

25. Welzel, P. et al. Moenomycin A: minimum structural requirements for biological activity. Tetrahedron 43, 585-598 (1987).

26. El-Abadla, N. et al. Moenomycin A: the role of the methyl group in the moenuronamide unit and a general discussion of structure-activity relationships. Tetrahedron 55, 699-722 (1999).

27. Sofia, M. J. et al. Discovery of novel disaccharide antibacterial agents using a combinatorial library approach. J. Med. Chem. 42, 3193-3198 (1999).

28. Baizman, E. R. et al. Antibacterial activity of synthetic analogs based on the disaccharide structure of moenomycin, an inhibitor of bacterial transglycosylase. Microbiology 146, 3129-3140 (2000).

29. Halliday, J., McKeveney, D., Muldoon, C., Rajaratnam, P. \& Meutermans, W. Targeting the forgotten transglycosylases. Biochem. Pharmacol. 71, 957-967 (2006).

30. Shih, H. W. et al. Effect of the peptide moiety of lipid II on bacterial transglycosylase. Angew. Chem. Int. Ed. 51, 10123-10126 (2012).

31. Kuhn, H. et al. Anti-bacterial glycosyl triazoles - Identification of an $\mathrm{N}$-acetylglucosamine derivative with bacteriostatic activity against Bacillus. Med. Chem. Commun. 5, 1213-1217 (2014).
32. Dumbre, S. et al. Synthesis of modified peptidoglycan precursor analogues for the inhibition of glycosyltransferase. J. Am. Chem. Soc. 134, 9343-9351 (2012).

33. Cheng, T.-J. R. et al. High-throughput identification of antibacterials against methicillin-resistant Staphylococcus aureus (MRSA) and the transglycosylase. Bioorg. Med. Chem. 18, 8512-8529 (2010).

34. Huang, S. H. et al. New continuous fluorometric assay for bacterial transglycosylase using Forster resonance energy transfer. J. Am. Chem. Soc. 135, 17078-17089 (2013).

35. Gampe, C. M., Tsukamoto, H., Doud, E. H., Walker, S. \& Kahne, D. E. Tuning the moenomycin pharmacophore to enable discovery of bacterial cell wall synthesis inhibitors. J. Am. Chem. Soc. 135, 3776-3779 (2013).

36. Wang, Y. et al. Structure-based design, synthesis, and biological evaluation of isatin derivatives as potential glycosyltransferase inhibitors. Chem. Biol. Drug Des. 84, 685-696 (2014).

37. Abbenante, G. et al. Biological diversity from a structurally diverse library: systematically scanning conformational space using a pyranose scaffold. J. Med. Chem. 53, 5576-5586 (2010).

38. Le, G. T. et al. Molecular diversity through sugar scaffolds. Drug Discov. Today 8, 701-709 (2003).

39. Ge, M. et al. Vancomycin derivatives that inhibit peptidoglycan biosynthesis without binding D-Ala-D-Ala. Science 284, 507-511 (1999).

40. Lugtenberg, E. J. J., Van Schijndel-Van Dam, A. \& Van Bellegem, T. H. M. In vivo and in vitro action of new antibiotics interfering with the utilization of $\mathrm{N}$-acetylglucosamine- $\mathrm{N}$-acetylmuramyl-pentapeptide. J. Bacteriol. 108, 20-29 (1971).

41. Somner, E. A. \& Reynolds, P. E. Inhibition of peptidoglycan biosynthesis by ramoplanin. Antimicrob. Agents Chemother. 34, 413-419 (1990).

42. Ruzin, A. et al. Further evidence that a cell wall precursor [C(55)-MurNAc(peptide)-GlcNAc] serves as an acceptor in a sorting reaction. J. Bacteriol. 184, 2141-2147 (2002).

43. Wu, M., Maier, E., Benz, R. \& Hancock, R. E. Mechanism of interaction of different classes of cationic antimicrobial peptides with planar bilayers and with the cytoplasmic membrane of Escherichia coli. Biochemistry 38, 7235-7242 (1999).

44. Chia, C. S., Gong, Y., Bowie, J. H., Zuegg, J. \& Cooper, M. A. Membrane binding and perturbation studies of the antimicrobial peptides caerin, citropin, and maculatin. Biopolymers 96, 147-157 (2011).

45. Giacometti, A. et al. In vitro activity and killing effect of citropin 1.1 against Gram-positive pathogens causing skin and soft tissue infections. Antimicrob. Agents Chemother. 49, 2507-2509 (2005).

46. Wegener, K. L. et al. Host defence peptides from the skin glands of the Australian blue mountains tree-frog Litoria citropa. Solution structure of the antibacterial peptide citropin 1.1. Eur. J. Biochem. 265, 627-637 (1999).

47. Lloyd, A. J. et al. Characterization of tRNA-dependent peptide bond formation by MurM in the synthesis of Streptococcus pneumoniae peptidoglycan. J. Biol. Chem. 283, 6402-6417 (2008).

48. Heaslet, H., Shaw, B., Mistry, A. \& Miller, A. A. Characterization of the active site of $S$. aureus monofunctional glycosyltransferase (Mtg) by site-directed mutation and structural analysis of the protein complexed with moenomycin. J. Struct. Biol. 167, 129-135 (2009).

49. Huang, C.-Y. et al. Crystal structure of Staphylococcus aureus transglycosylase in complex with a lipid II analog and elucidation of peptidoglycan synthesis mechanism. Proc. Natl Acad. Sci USA 109, 6496-6501 (2012).

50. Lovering, A. L., de Castro, L. H., Lim, D. \& Strynadka, N. C. J. Structural insight into the transglycosylation step of bacterial cell-wall biosynthesis. Science $\mathbf{3 1 5}$, 1402-1405 (2007).

51. Lovering, A. L., De Castro, L. \& Strynadka, N. C. Identification of dynamic structural motifs involved in peptidoglycan glycosyltransfer. J. Mol. Biol. 383, 167-177 (2008).

52. Sung, M.-T. et al. Crystal structure of the membrane-bound bifunctional transglycosylase PBP1b from Escherichia coli. Proc. Natl Acad. Sci. USA 106, 8824-8829 (2009).

53. Yuan, Y. et al. Crystal structure of a peptidoglycan glycosyltransferase suggests a model for processive glycan chain synthesis. Proc. Natl Acad. Sci. USA 104, 5348-5353 (2007).

54. Zuegg, J. \& Meutermans, W. Crystal structures of the PBP2 glycosyltransferase domain: new opportunities for antibacterial drug design. ChemMedChem 2, 1403-1404 (2007).

55. Oki, M. in Top. Stereochem. (eds Allinger, N. L., Eliel, N. L. \& Wilen, S. H.) Vol. 14, 1-81 (John Wiley \& Sons, 1983).

56. Laplante, S. R. et al. Assessing atropisomer axial chirality in drug discovery and development. J. Med. Chem. 54, 7005-7022 (2011).

57. Riedl, S., Ohlsen, K., Werner, G., Witte, W. \& Hacker, J. Impact of flavophospholipol and vancomycin on conjugational transfer of vancomycin resistance plasmids. Antimicrob. Agents Chemother. 44, 3189-3192 (2000). 
58. Friesner, R. A. et al. Glide: a new approach for rapid, accurate docking and scoring. 1. Method and assessment of docking accuracy. J. Med. Chem. 47, 1739-1749 (2004).

59. Sherman, W., Beard, H. S. \& Farid, R. Use of an induced fit receptor structure in virtual screening. Chem. Biol. Drug Des. 67, 83-84 (2006).

60. Sherman, W., Day, T., Jacobson, M. P., Friesner, R. A. \& Farid, R. Novel procedure for modeling ligand/receptor induced fit effects. J. Med. Chem. 49, 534-553 (2006).

61. Reynolds, P. E. Peptidoglycan synthesis in bacilli. I. Effect of temperature on the in vitro system from Bacillus megaterium and Bacillus stearothermophilus. Biochim. Biophys. Acta 237, 239-254 (1971).

62. Schwartz, B., Markwalder, J. A., Seitz, S. P., Wang, Y. \& Stein, R. L. A kinetic characterization of the glycosyltransferase activity of Escherichia coli PBP1b and development of a continuous fluorescence assay. Biochemistry 41, 12552-12561 (2002).

63. Prasad, L. B. \& Newbould, F. H. Inoculation of the bovine teat duct with Staphylococcus aureus: the relationship of teat duct length, milk yield and milking rate to development of intramammary infection. Can. Vet. J. 9, 107-115 (1968).

64. Demon, D. et al. The intramammary efficacy of first generation cephalosporins against Staphylococcus aureus mastitis in mice. Vet. Microbiol. 160, 141-150 (2012).

\section{Acknowledgements}

This work was supported by Alchemia Ltd, Bayer A.H. (for mouse S. aureus mastitis study), NHMRC Australia Fellowship AF 511105 to M.A.C., BBSRC PhD studentship to N.F.G. and MRC research grants G1100127, G500643 and G0600801 as well as Wellcome Trust equipment grants 071998 and 068598 to D.I.R. and C.G.W. A.J.L. was supported by the Birmingham-Warwick Science City initiative, and T.-J.C. and W.-C.C. were supported by Academia Sinica and Ministry of Science and Technology. We thank David L. Paterson (UQCCR, University of Queensland, Brisbane, Australia) for his kind donation of clinical Gram-positive isolates, as well as Professor Joan Faoagali and Dr Narelle
George from the Queensland Health Pathology and Scientific Services (QHPS, Queensland Health, Brisbane, Australia) for the MIC testing of actives against a panel of bacterial strains including clinical isolates.

\section{Author contributions}

C.M., G.A., D.M., G.L.T., R.P., B.B., L.S. and J.S. developed the chemistry and performed the synthesis, with J.Z. contributing to the design of the library. M.C., A.G.E., J.X.H., M.S.B., T.-J.C., W.-C.C., N.F.G., D.I.R., A.J.L. and C.G.D. developed, performed or supervised the various biochemical assays including analytical methods. D.D. and E.M. performed the in vivo assays. J.Z. and M.B. performed the in silico experiments. J.Z., C.M and M.S.B. contributed to the writing of the manuscript. W.M. and M.A.C. supervised the studies, with W.M. establishing the project.

\section{Additional information}

Supplementary Information accompanies this paper at http://www.nature.com/ naturecommunications

Competing financial interests: The authors declare no competing financial interests.

Reprints and permission information is available online at http://npg.nature.com/ reprintsandpermissions/

How to cite this article: Zuegg, J. et al. Carbohydrate scaffolds as glycosyltransferase inhibitors with in vivo antibacterial activity. Nat. Commun. 6:7719 doi: $10.1038 /$ ncomms8719 (2015).

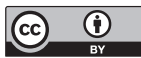

This work is licensed under a Creative Commons Attribution 4.0 International License. The images or other third party material in this article are included in the article's Creative Commons license, unless indicated otherwise in the credit line; if the material is not included under the Creative Commons license, users will need to obtain permission from the license holder to reproduce the material. To view a copy of this license, visit http://creativecommons.org/licenses/by/4.0/ 